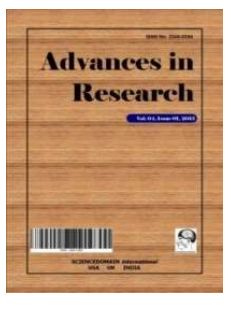

\title{
Advances in Research
}

10(2): 1-14, 2017; Article no.AIR.33850

ISSN: 2348-0394, NLM ID: 101666096

\section{Status of Fish Aggregating Device Fishery in the River Titas of Bangladesh}

\author{
M. G. Mustafa ${ }^{1^{\star}}$ \\ ${ }^{1}$ World Fish, South Asia Office, House 22B, Road 7, Block F, Banani, Dhaka-1213, Bangladesh.
}

Author's contribution

The sole author designed, analyzed and interpreted and prepared the manuscript.

Article Information

DOI: $10.9734 / \mathrm{AIR} / 2017 / 33850$

Editor(s):

(1) Marco Trevisan, Faculty of Agricultural Sciences, Institute of Agricultural and Environmental Chemistry, Catholic University

of the Sacred Heart, Italy.

Reviewers:

(1) Cocan Daniel Ioan, University of Agricultural and Veterinary Medicine Cluj-Napoca, Romania.

(2) Carmen Georgeta Nicolae, University of Agronomic Sciences and Veterinary Medicine of Bucharest, Romania.

(3) Siripavee Charoenwattanasak, Khon Kaen University, Khonkaen, Thailand

Complete Peer review History: http://www.sciencedomain.org/review-history/19628

Original Research Article

Received $1^{\text {st }}$ March 2017

Accepted $8^{\text {th }}$ June 2017

Published $21^{\text {st }}$ June 2017

\begin{abstract}
Aims: To examine the status of Fish Aggregating Device (Katha) fishery in the river Titas in Bangladesh and development of an alternative Katha fishery management strategy.

Study Design: All Fish Aggregating Devices (Kathas) were recorded through a census survey. Fish catch monitoring facilitated through a regular catch survey of Katha/gear/team in operation.

Place and Duration of Study: The study employed data collected from the river Titas in Brahmanbaria district of Bangladesh from 1997 to 2002.

Methodology: A census of all constructed Fish Aggregating Devices (Kathas) in the study sites was undertaken. Catch data, including information on species composition and abundance, were collected from Katha fishers during the harvest season. Simultaneously a robust catch assessment was observed for four days per month. Randomly selected samples of catch by species by gear are recorded for each gear type.

Results: Katha fisheries in this river accounted for $28 \%, 20 \%, 34 \%, 34 \%, 37 \%$ and $25 \%$ of annual fish production in 1997, 1998, 1999, 2000, 2001 and 2002 respectively. Significant $(p<0.001)$ differences in species assemblages between Katha and survey catch were found in this river. However, species distributions in Katha catch are not significantly different in the years 1997 to 2002 at the $5 \%$ level.

Conclusion: Katha fishery in the river system generally has a detrimental impact on fisheries resources as well as reducing fishing opportunities for poor and marginal fishers.
\end{abstract}


Keywords: Fish aggregating devices; catch monitoring; species assemblage; biodiversity.

\section{INTRODUCTION}

The fisheries sector in Bangladesh is the most important as a source of food, livelihoods and employment opportunity provider. The country's annual fish production has increased from 1.087 million tonnes in 1993-94 to about 3.41 million tonnes in 2012-13 [1]. Fish provides $60 \%$ of national animal protein consumption [2]. In addition, the fishing provides directly or indirectly employment to nearly 17.1 million people [1]. Inland fisheries remain the most important contributor to fish production in Bangladesh and administered to generate government revenue without due concern for sustainability [3]. Fish aggregating device (Katha) fishery in the river Titas is one of the important fishery. A Katha is actually a brush shelter used as a fish aggregating device. The main component of a Katha is a composition branches of local trees such as Mango, Blackberry tree (Jam), Wood Apple (Bel), B. acutungula (Hizol), T. aspera (Shawra) and aquatic weeds [4]. The Katha materials can be divided into two major types: underwater brushes and surface shade parts. Branches provide hiding places and shelter, and the floating aquatic weeds are used as shade as they provide a darker area where fish can hide easily. In a way Kathas mimic a flooded part of the river. Long bamboos and ropes are used to encircle the Katha boundaries and to fix aquatic floating weeds. It provides temporary shelter for many small, medium and large sized fishes. When the branches deteriorate, many organisms such as prawns feed on periphytes which grow on the branches. This is also thought to be an important source of food for omnivorous fish species. The small cat fish (Mystus vittatus) showed specific preference to Khata made by bamboo roots in the river [5]. The establishment of Katha as fish sanctuary in the beel (deeper depression in floodplains) had beneficial effects on the production of fish $[6,7]$. A census of Katha was conducted in Ashura beel, Goakhola beel and Dikshi beel in Bangladesh from 1997 to 2002 and species composition and abundance were assessed [8].

When water levels fall at the end of the monsoon, fishes start to migrate from floodplains to shelter in deeper waters during the winter (dry season). So Kathas are normally constructed from September onwards, following fish behaviour. The timing of Katha construction is also related to flood duration in each year. A late flood results in a delay in Katha construction. Katha are sometimes constructed in beels (Floodplain usually with a permanent water body), but are most common in rivers, where they are placed between the bank side of the river and the middle of the river. In some cases like closed rivers or the dead channel of rivers, mid-channel Kathas are also observed.

The study employed data collected from the river Titas (Goshipur to Gokornaghat) under Community Based Fisheries Management Project (CBFM) from 1997 to 2002. The river part is located in Brahmanbaria district of Bangladesh (Fig. 1). Status of Katha fisheries were examined in three ways. Firstly, by using data from Katha catch in estimates of fisheries production and biodiversity trends. Secondly, by using species data from Katha and survey catch for determining species abundance for open water fisheries resources management. Finally, by using cost-benefit data from Katha preparation and harvest for determining profit.

\section{METERIALS AND METHODS}

\subsection{Katha (Fish Aggregation Device) Census}

A census of all constructed Kathas in the study sites was undertaken from 1997 to 2002. Catch data, including information on species composition and abundance, were collected from fishers during the harvest season. Annual catches from Kathas were based on the total seasonal harvest and expressed as catch per hectare of Katha per year (kg/ha).

\subsection{Catch and Gear Survey}

Fishing activity was observed for four days per month $(m)$, continuously for 72 months. Gear surveys involved a regular spot survey for a sample of gears in operation, and the total catch from each gear type $(g)$. A gear census covered the number and types of gear operating in the study sites. The species-wise catch of gear $g$ for month $\mathrm{m}$ was estimated as the product of the mean catch rate for gear $\mathrm{g}$, the average number of fishing units operating of type $\mathrm{g}$, and the number of days in the month. The average number of gear units per day was used to 
estimate total gear-wise fishing effort for that month as well as for the whole year. Mean gear-wise catch rate was used to estimate total catch for that month, as well as for the whole year. Annual catch per unit area (CPUA) was employed as a measure of fish production in the river:

$$
C P U A=\frac{\sum_{m=\text { Jan }}^{m=\text { Dec }} \sum_{g=1}^{n} \text { Catch }_{m, g}}{\text { AverageArea }}
$$

Where Catch $_{m, g}$ is the estimated catch landed by gear type $\mathrm{g}$, during month $\mathrm{m}$ as well as year in the river measured in $\mathrm{kg} / \mathrm{ha}$.

\subsection{Multivariate Comparisons of Species Assemblage between Katha and Survey Catch}

Multivariate comparisons of fish diversity were also performed by comparing abundance indices (annual catch rate per hectare (kg) by species from 1997 to 2002) of species forming the multispecies assemblage between Katha catch and Survey catch.

Similarities in the species assemblages at Katha catch and Survey catch were summarised in two-dimensional space using nonparametric multidimensional scaling (MDS) ordinations following a strategy proposed by [9]. The approach aims to construct a map or ordination of years (samples) such that their placement reflects the rank similarity of their species assemblages. Years positioned in close proximity to each other in the ordination have very similar species assemblages, whilst years that are far apart share few common species, or have the same species but at a very different levels of abundance. A "stress" measure indicates how well the ordination satisfies the (dis)similarities between Katha and Survey catches. Stress values $<0.2$ indicate acceptable fits to the data. The null hypothesis $\left[H_{0}\right]$ was tested using a nonparametric permutation (analysis of similarity or ANOSIM) test based upon the difference in the average rank similarity within and between the Katha catch and Survey catch year groups ( $r$ statistic). The significance level of the test is calculated by referring the observed value of the $r$ statistic to its permutation distribution generated from randomly sampled sets of permutations of site labels.
The species most responsible for the year groupings were then determined by computing the average contribution of each species to the overall average dissimilarity between all pairs of intergroup years. The MDS and ANSOSIM analyses were performed with the Community Analysis packages software [10] and employing the Bray-Curtis [11].

\subsection{Shannon-Wiener Diversity Index}

The Shannon-Wiener Index $\left(\mathrm{H}^{\prime}\right)$ is one of several indices used to measure biodiversity. The function is defined as:

$$
H^{\prime}=-\sum_{i=1}^{s} p_{i} \ln p_{i}
$$

Where $s=$ number of species and $p_{i}=$ the proportion of individuals from the $i^{\text {th }}$ species in the sample.

\subsection{Species Abundance and Distributions}

Truncated log normal model is one of indicated to measure species abundance relationship. If the value of $p$ is $<0.05$ then the distributions are significantly different at the $5 \%$ level.

The log series distribution is described by:

$\alpha \times, \frac{\alpha \times}{2}, \frac{\alpha \times}{3}, \ldots \ldots . \frac{\alpha \times}{n}$

Where, each term gives the number of species predicted to have $1,2,3 \ldots \mathrm{n}$ individuals in the sample. The parameter $\alpha$ is estimated by iteration, after which $\mathrm{x}$ is calculated.

The species abundance and distributions analyses were performed with the Species Diversity and Richness software [12] and employing the Truncated Log Normal model.

\section{RESULTS AND DISCUSSION}

\subsection{Landownership Category of Katha Owner}

Katha census data revealed that the total number of Katha was almost constant at 49 or 50 each year. All existing Kathas were categorised into 4 types according to the land ownership pattern of Katha main owner using following criteria: 
Table 1. Landownership category of Katha owner

\begin{tabular}{lll}
\hline No & Type & $\begin{array}{l}\text { Land ownership } \\
\text { patterns of main } \\
\text { owner }\end{array}$ \\
\hline 1 & Landless & $<0.2 \mathrm{ha}$ \\
2 & Small farmers & $0.2-1.01 \mathrm{ha}$ \\
3 & Medium farmers & $1.01-3.04 \mathrm{ha}$ \\
4 & Large farmers & $>3.04 \mathrm{ha}$ \\
\hline
\end{tabular}

The average size of Katha varied from year to year with a maximum of 1.19 ha in 1999 and a minimum of 0.75 ha in 1998. The size range of Kathas in different study years' reveals that most were in the size range of $0.5-1.0$ ha during 1997 and 1998 however larger size ranges became more common during 2000 to 2002. More than $90 \%$ of Kathas lie within the size range of $0.8-1.3$ ha.

Land ownership category of Katha owners reveals that Medium and Small farmers own the Kathas rather than fishermen or landless people. Analysis of Katha ownership characteristics (\% by number of Kathas) for the six years (19972002) was $4.26 \%, 44.68 \%, 48.94 \%$ and $2.13 \%$ for Landless, Small farmer, Medium farmer and Large farmer respectively. The area covered by Katha according to ownership category was 3\%, $33 \%, 60 \%$ and $4 \%$ for the Landless, Small farmers, Medium farmers and Large farmers' group respectively (Fig. 2). Overall, $93 \%$ of the area covered by Kathas is owned by the farmers' groups.

\subsection{Setting and Harvesting Season}

Setting of Katha started in Aswin-Kartik (mid September to mid November) of the year following the draw-down phase of the monsoon. Harvesting started 1-2 months after the Katha was set, usually in the month of Poush ${ }^{*}$ (mid December to mid January) and continued up to

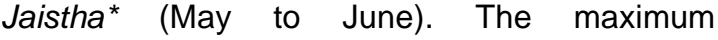
numbers of Kathas are operated during the months of Poush-Baisakh (mid December to mid May).

Harvesting is accomplished by encircling the Katha carefully with a small mesh seine net from the bottom to 0.6 meters above the water level before harvesting. Intensive harvest (> 20 numbers of Katha per month) continued for 3 to 4 months (Jan to April), and overall harvest

"Months of the Bengali year
( $<10$ numbers of Katha per month) periods continued for up to 6 months (Dec to May) in a year. A single Katha was repetitively harvested 2 to 3 times in a season. The average harvested ratio (Katha: harvest) for Kathas in 1997, 1998, 1999, 2000, 2001 and 2002 were 1:2.18, $1: 2, \quad 1: 2.33, \quad 1: 2.28, \quad 1: 3.12$ and 1:2.45 respectively.

\subsection{Analysis of Katha Catches}

Analysis of Katha catches was done for the years 1997-2002 using catch monitoring records. During the study period, a total of 51 fishes/ prawns and two unidentified fish species were recorded. To simplify the analysis, fishes were divided into eight major groups based on taxonomic hierarchy, food habits and fish size as outlined in Table - 2.

In general, Katha catches are different from normal riverine catches. Katha catches in Titas Goshipur to Gokornaghat section were dominated by different kind of prawns, catfishes and carps. It is believed that small fish find shelter in Kathas whereas predatory species also find Kathas attractive as it is a good area for their prey. So Katha habitats are a unique mixture of predators and prey. The total catch from Kathas varied between years. Analysis of the catch data for the six years (1997-2002) gave annual estimates of fisheries production $(\mathrm{kg} / \mathrm{ha})$ of $304,474,558$, 675,763 and 762 respectively. The catch trend appears to be upwards with 2002 catch levels $151 \%$ higher than those in 1997. The trends in fish production from Katha fisheries are shown in Fig. 3.

\subsection{Biodiversity and Species Abundance}

The total number of species recorded varied from 28 species in 1998 and 2001 to 37 species in 2000. The actual numbers were $35,28,32,37$, 28 and 34 in the years between 1997 and 2002 respectively. The biodiversity measured using the Shannon-Weiner index $\left(\mathrm{H}^{\prime}\right)$ was found to be $2.77,2.98,2.92,2.89,2.81$ and 2.85 in the years between 1997 and 2002 respectively. Preferences of fishes to different types of Katha materials has been studied by [13] from three rivers in Bangladesh and they found maximum number of species (40) in the traditional Katha (Katha with tree branches) and minimum (30) in the bamboo root Katha. A total number of 84 aquatic species (71 wild fishes, five prawns, one crab, four snails and three freshwater turtles) were recorded in the Haria beel in Bangladesh 
and Fish aggregating device (Katha) methods was detected as detrimental killing methods for all types of species [14]. The natural production of aquatic life in the Someswari River in northern Bangladesh declined dramatically during 2001-2005 and total production of the river decreased from 95.79 to $38.61 \mathrm{mt}$ [15]. [16] also reported that the use of Fish Aggregating Device (Katha) was increased during 2008-2010 from $9.10 \%$ to $14.30 \%$ in the Meduary beel in Bangladesh.
The results of a Chi-Squared test for species abundance relationship from 1997 to 2002 are given in table 2 . The $p$ values were found $>0.25$ indicated that the species distributions are not significantly different in the years between 1997 and 2002 at $5 \%$ level. The data for each year fits a truncated log normal model. The species abundance classes show a plot of the observed (histogram) and expected (line) frequency distributions arranged by class for the six years (Fig. 4).

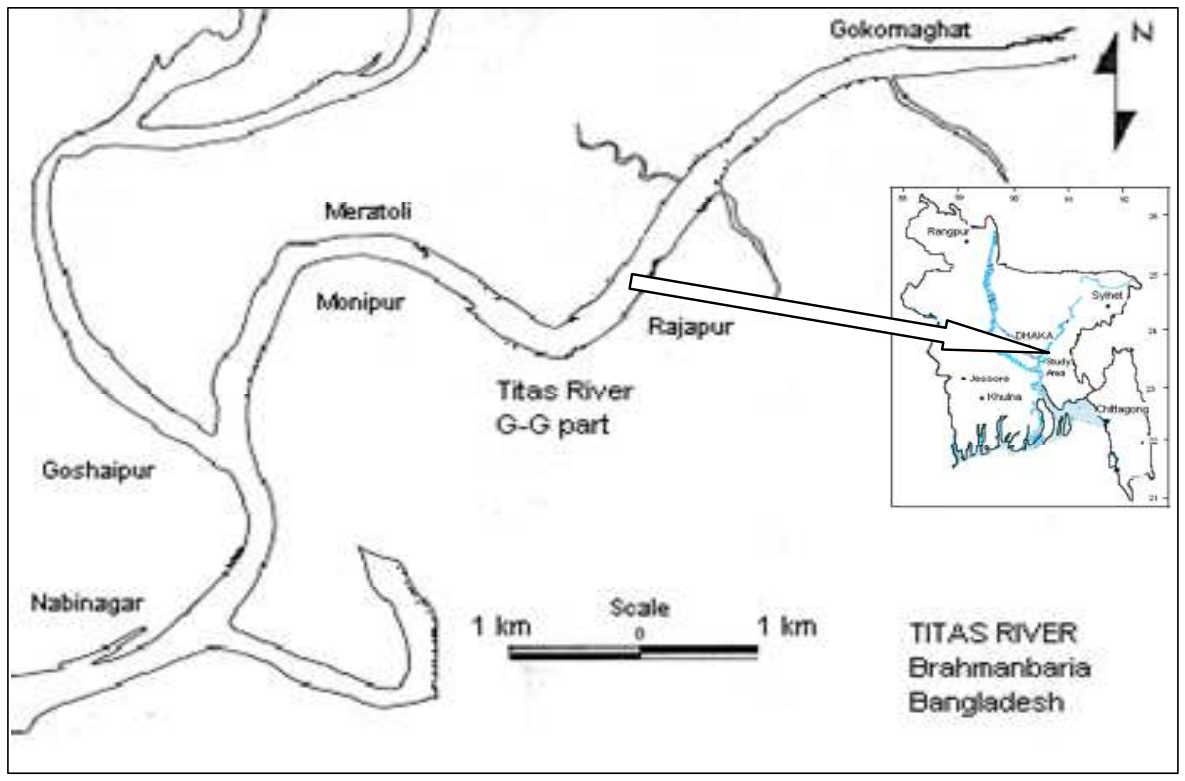

Fig. 1. Study area of the river Titas (Goshipur to Gokornaghat section), Brahmanbaria district, Bangladesh

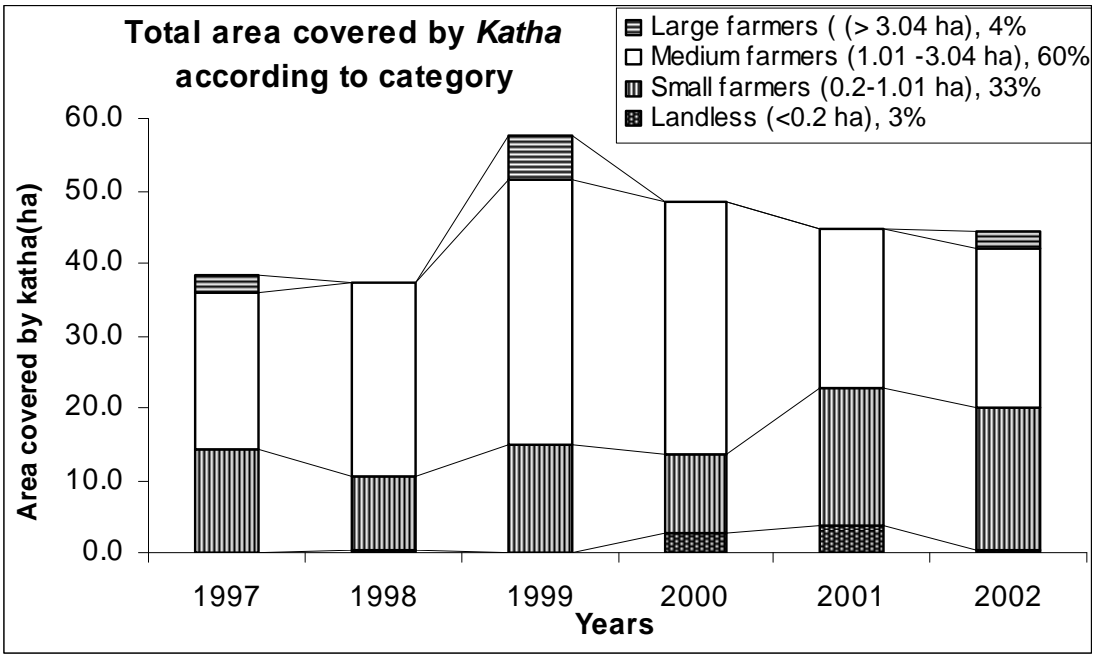

Fig. 2. Area covered by Katha according to Katha owner categories 
Table 2. The habitat group, scientific name and common name used in the Katha catch analysis of the river Titas G-G part

\begin{tabular}{|c|c|c|c|}
\hline SI No. & Habitat group & Taxonomic: Scientific name & $\begin{array}{l}\text { Common name: Species within } \\
\text { group }\end{array}$ \\
\hline 1. & $\begin{array}{l}\text { Large and medium } \\
\text { sized cat fishes }\end{array}$ & $\begin{array}{l}\text { Sperata aor, Mystus bleekeri, } \\
\text { Ompok pabda, Ompok } \\
\text { bimaculatus, Wallago attu, } \\
\text { Heteropneustes fossilis, Clarias } \\
\text { batrachus, Rita rita }\end{array}$ & $\begin{array}{l}\text { Long-whiskered catfish, Day's } \\
\text { maystus, Pabda catfish, Butter } \\
\text { catfish, Wallago catfish, Stinging } \\
\text { catfish, Philippine catfish, Rita }\end{array}$ \\
\hline 2. & Small cat fishes & $\begin{array}{l}\text { Mystus vittatus, Mystus sp., } \\
\text { Neotropius neotropius, } \\
\text { Pseudeutropius sp., Sperata } \\
\text { seenghala. }\end{array}$ & $\begin{array}{l}\text { Striped dwarf catfish, Catfish, } \\
\text { Indian potasi, Batasi, Giant river- } \\
\text { catfish. }\end{array}$ \\
\hline 3. & $\begin{array}{l}\text { Major and minor } \\
\text { carps }\end{array}$ & $\begin{array}{l}\text { Labeo rohita, Gibelion catla, } \\
\text { Cyprinus carpio, Cirrhinus } \\
\text { mrigala, Labeo gonius, Labeo } \\
\text { calbasu, Systomus sarana. }\end{array}$ & $\begin{array}{l}\text { Roho labeo, Catla, Common carp, } \\
\text { Carps, Kuria labeo, Orangefin } \\
\text { labeo, Olive bard }\end{array}$ \\
\hline 4. & Prawns & $\begin{array}{l}\text { Macrobrachium malcolmsonii, } \\
\text { Macrobrachium villosimanus, } \\
\text { Macrobrachium rogenbergii, } \\
\text { Macrobrachium lamarrei and } \\
\text { Macrobrachium birmanicum }\end{array}$ & $\begin{array}{l}\text { Monsoon river prawn, Dimua river } \\
\text { prawn, Giant river prawn, Kuncho } \\
\text { river prawn and Birma river prawn }\end{array}$ \\
\hline 5. & Snake heads & $\begin{array}{l}\text { Channa marulius, Channa striata } \\
\text { and Channa punctata }\end{array}$ & $\begin{array}{l}\text { Great snakehead, Striped } \\
\text { snakehead and Spotted } \\
\text { snakehead }\end{array}$ \\
\hline 6. & Small barbs & $\begin{array}{l}\text { Puntius sophore, Pethia gelius, } \\
\text { Pethia conchonius, Pethia } \\
\text { phutunio, Pethia ticto }\end{array}$ & $\begin{array}{l}\text { Pool barb, Golden barb, Rosy } \\
\text { barb, Spottedsail barb, Ticto barb }\end{array}$ \\
\hline 7. & $\begin{array}{l}\text { Large and medium } \\
\text { miscellaneous } \\
\text { species }\end{array}$ & $\begin{array}{l}\text { Notopterus notopterus, Chitala } \\
\text { chitala, Mastacembelus armatus } \\
\text { and Nandus nandus }\end{array}$ & $\begin{array}{l}\text { Bronze featherback, Clown } \\
\text { knifefish, Zig-zag eet and Gangetic } \\
\text { leaffish }\end{array}$ \\
\hline 8. & $\begin{array}{l}\text { Small } \\
\text { miscellaneous } \\
\text { species }\end{array}$ & $\begin{array}{l}\text { Parambassis ranga, } \\
\text { Parambassis sp., Trichogaster } \\
\text { fasciata, Macrognathus } \\
\text { pancalus, Trichogaster lalius, } \\
\text { Chala cachius, Trichogaster } \\
\text { chuna, Salmophasia sp., } \\
\text { Nemacheilus sp., Osteobrama } \\
\text { cotio, Tetradon sp., } \\
\text { Amblypharyngodon mola, } \\
\text { Gudusia chapra, Badis badis and } \\
\text { two unidentified fish species. }\end{array}$ & $\begin{array}{l}\text { Indian glassy fish, Glassy fish, } \\
\text { Banded gourami, Barred spiny eel, } \\
\text { Dwarf gourami, Minnows, Honey } \\
\text { gourami, Finescale razorbelly } \\
\text { minnow, Loach, Minnows, } \\
\text { Milkspotted puffer, Mola carplet, } \\
\text { Indian river shad, Badis and two } \\
\text { unidentified fish species. }\end{array}$ \\
\hline
\end{tabular}

Table 3. Chi-Squared results on species abundance in the river Titas

\begin{tabular}{lllllll}
\hline Years & $\begin{array}{l}\text { Observed } \\
\text { log 10 mean }\end{array}$ & $\begin{array}{l}\text { Total } \\
\text { species }\end{array}$ & Chi & $\begin{array}{l}\text { Degrees of } \\
\text { freedom }\end{array}$ & p values & $\begin{array}{l}\text { Diversity of } \\
\text { statistics }\end{array}$ \\
\hline 1997 & 0.997 & 35 & 2.867 & 6 & 0.825 & 47.47 \\
1998 & 1.281 & 28 & 6.417 & 5 & 0.267 & 48.93 \\
1999 & 1.274 & 32 & 4.472 & 5 & 0.448 & 50.09 \\
2000 & 1.152 & 37 & 6.193 & 6 & 0.401 & 47.11 \\
2001 & 1.413 & 28 & 2.464 & 4 & 0.651 & 59.83 \\
2002 & 1.127 & 34 & 5.342 & 6 & 0.500 & 45.69 \\
\hline
\end{tabular}




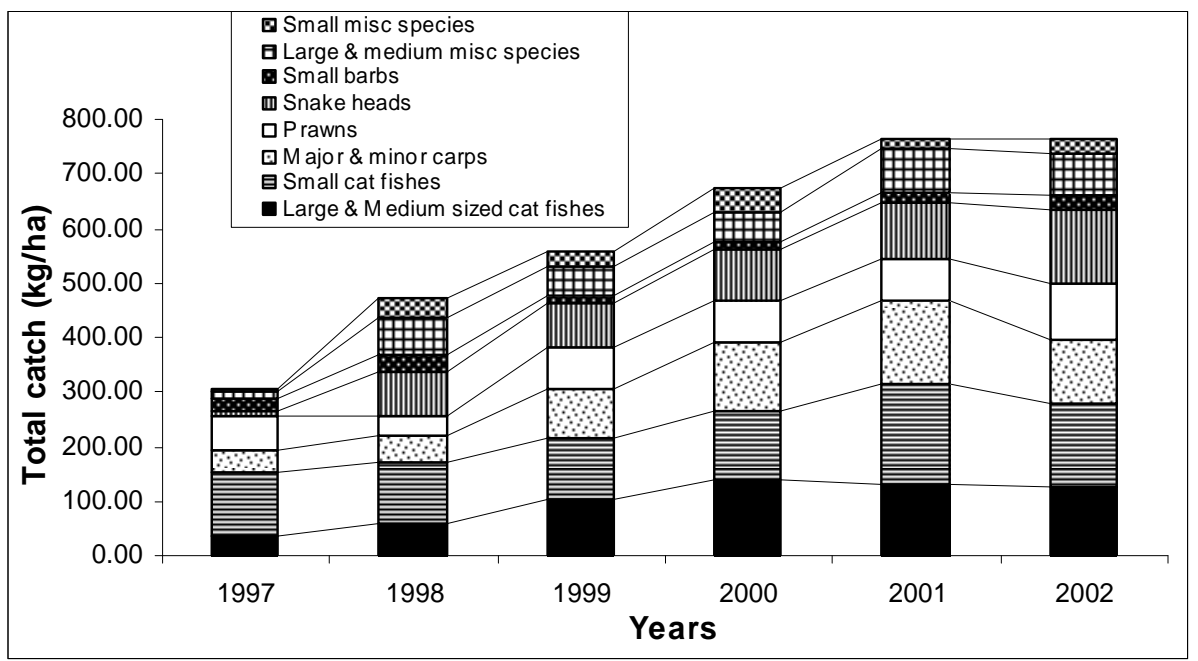

Fig. 3. Annual trends of Katha catches in the river Titas (Legend: top to bottom; Small misc. species to Large and Medium sized cat fishes).

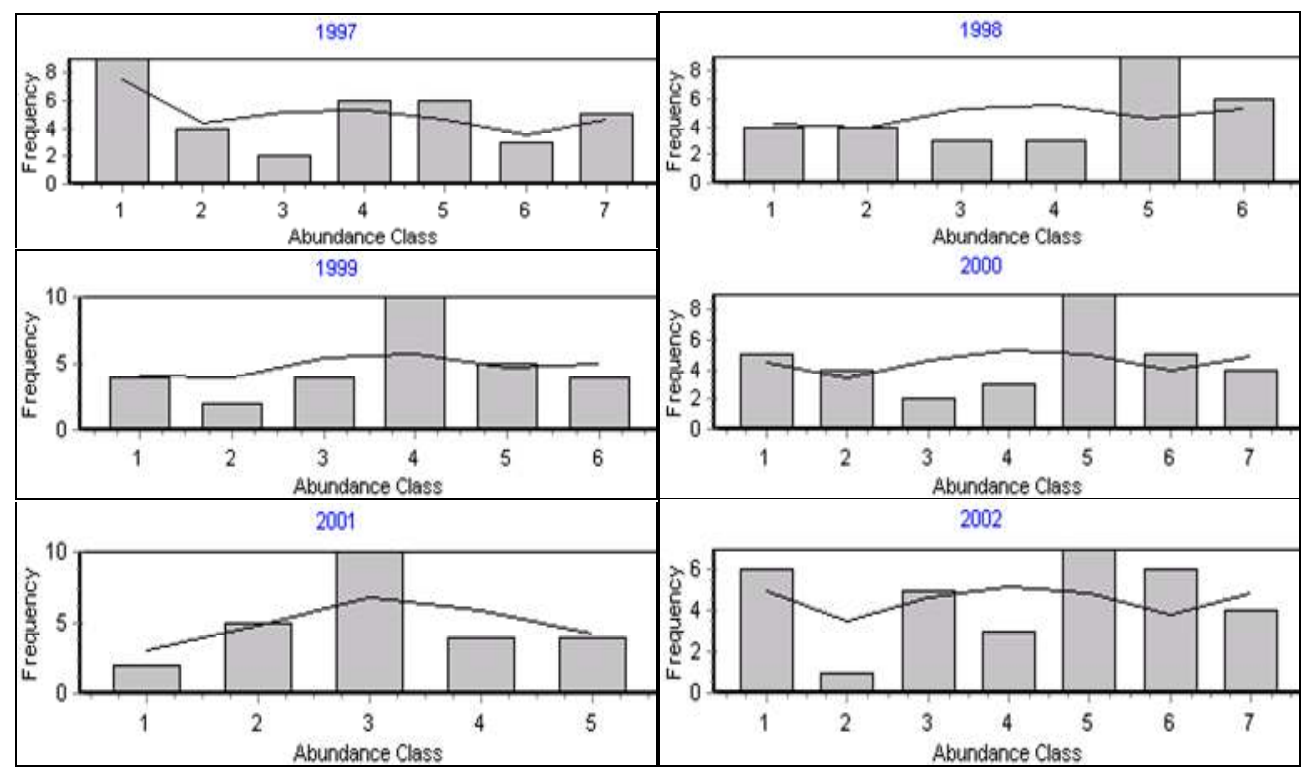

Fig. 4. Abundance class of species in Katha fishery (observed and expected frequency as histogram and line)

3.5 Multivariate Comparisons of Species Assemblage between Katha and Survey Catch

Significant $(p<0.001)$ differences in species assemblages in Katha catch and Survey catch were found in the river Titas (Fig. 5). Results from the one-way ANOSIM to test for differences in species assemblages between Katha catch (6 years) and Survey catch (6 years) reveals sample statistics and permutations were found to be 0.957 and 462 respectively. Stress vs. dimension shows decreasing trends and final stress value found to be $0.152,0.024$ and 0.016 for dimension 1, 2 and 3 respectively.

\subsection{Average Abundance of Species in Katha and Survey Catch}

Species assemblages in the Katha catch from 1997 to 2002 comprised less species than those of Survey catch. Of the 28 major contributed species $(90.82 \%), 22$ were more abundant in 


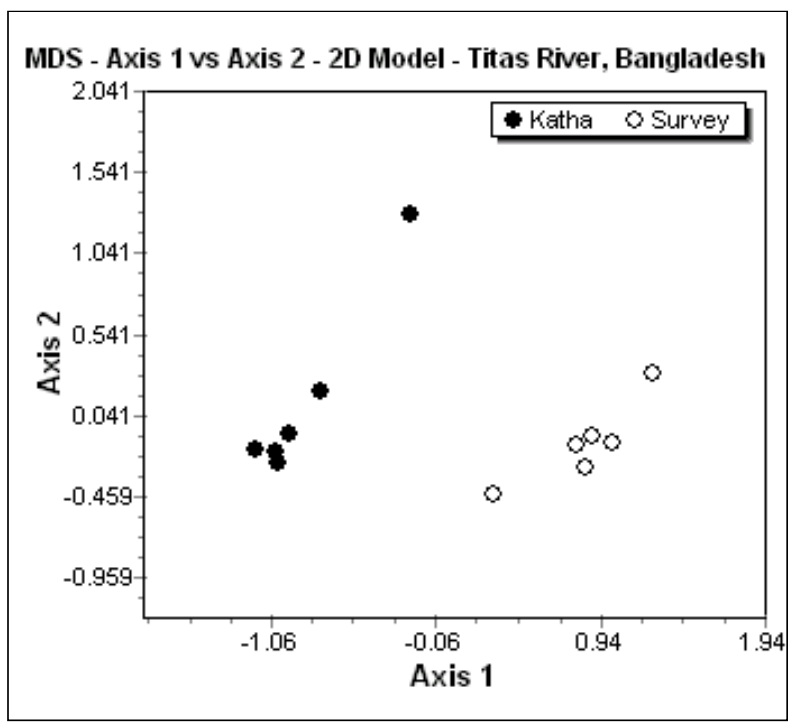

Fig. 5. MDS ordinations comparing species assemblages in Katha and Survey catch (Values of each species combination on the right-hand side, Axis 1 and Axis 2, on the left-hand side)

Katha catch. These included in descending order of their contribution to the average dissimilarity between the two types of fisheries: Mystus vittatus, Channa marulius, Wallago attu, Gudusia chapra, Corica soborna, Labeo rohita, Neotropius atherinoides, Puntius sophore, Channa striata, Macrobrachium rosenbergii, Mystus sp., Notopterus notopterus, Systomus sarana, Mystus bleekeri, Sperata aor, Labeo gonius, Macrobrachium malcolmsonii, Mastacembelus armatus, Xenentodon cancila, Macrobrachium lamarrei, Macrognathus aculeatus, Nandus nandus, Parambassis ranga, Labeo calbasu, Parambassis sp., Sperata seenghala, Ompok pabda, Macrobrachium villosimanus. These species are also members of both whitefish and blackfish. Only 6 species were more abundant at the Survey catch: Gudusia chapra, Puntius sophore, Corica soborna, Xenentodon cancila, Macrognathus aculeatus and Parambassis ranga. The species Corica soborna, Xenentodon cancila and Macrognathus aculeatus were absent in the Katha catch.

Species are arranged from top to bottom in descending order of their contributions to the average dissimilarity between the two fisheries (Katha and Survey catch) of different years. Only those species contributing to $67.94 \%$ of the cumulative average dissimilarity are shown in Fig. 6.

Among the taxonomic groups, Small catfish showed the highest catch, and followed by,
Large-medium sized catfish (Sperata aor and Wallago attu), Major and minor carps (Labeo rohita, Gibelion catla, Cirrhinus mrigala and Systomus sarana), Snakeheads (Channa marulius, Channa striata, Channa punctata), Prawns (Macrobrachium rosenbergii and Macrobrachium malcolmsonii), Large and medium miscellaneous species and Small miscellaneous species. The Pethia sp showed the lowest catch rate in all study years. Analyzing the annual data for the six sampling years (19972002), the compositions of species when comparing Katha catches with survey catches indicated large changes among groups.

\subsection{Detailed Description of Catches among Groups}

\subsubsection{Large and medium sized catfishes}

Fishes under this group are mainly carnivorous and top predators. A total of eight species were observed in this group. Wallago attu, a carnivorous fish and major contributed species in this group which showed increasing trend in production from 1997 to 2002. Production of Sperata aor gradually increased and reached a peak (27.89 kg/ha) in 2000 however, considerably declined $(7.4 \mathrm{~kg} / \mathrm{ha})$ in 2002 . Ompok pabda, the most commercial valuable species, showed fluctuating in Katha catches and the highest catch $(11.62 \mathrm{~kg} / \mathrm{ha})$ was found in 2001. The catch rate of Ompak bimaculatus was $4.73 \mathrm{~kg} / \mathrm{ha}$ in 1997, and showed a decreasing 


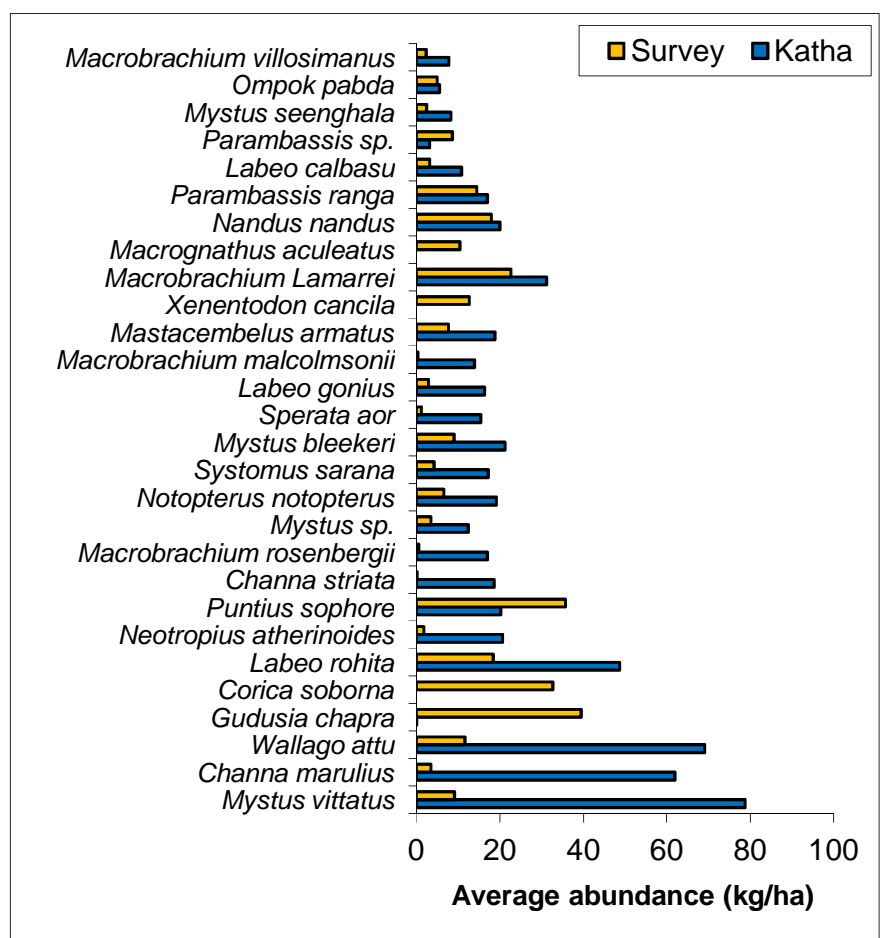

Fig. 6. Average abundance (catch $\mathrm{kg} / \mathrm{ha}$ ) of species caught form Katha and Survey catch in the river Titas

trend in following years and not found in Katha catches during 2001 and 2002. Species such as Heteropneustes fossilis, Clarias batrachus and Rita rita were made negligible contributions to the catches in this group. Family and species wise detailed results are given in Appendix-1.

\subsubsection{Small catfish}

Small catfish made up the highest contributions in Katha catches. Mystus vittatus is a small catfish of $3-5 \mathrm{~cm}$ (total length) and was the most prevalent species in this group. The production of Mystus vittatus increased with the highest catch of $130.82 \mathrm{~kg} / \mathrm{ha}$ appeared in 2001 . Family and species level detailed results are presented in Appendix-1.

\subsubsection{Major and minor carps}

Fishes under this group are mostly the local major carps (Labeo rohita, Gibelion catla, Cirrhinus mrigala, Labeo gonius, Labeo calbasu), and Cyprinus carpio (Common carp) and Systomus sarana (olive barbi). Among the major carps the most important commercial species Labeo rohita, makes up the maximum contribution and followed by Labeo calbasu and Labeo gonius. The highest catch $(65.63 \mathrm{~kg} / \mathrm{ha})$ of
Labeo rohita was recorded in 2001 which remained almost the similar from 2000 to 2002. Family and species level detailed results are also presented in Appendix-1.

\subsubsection{Prawns}

Prawns are one of the major contributory group in Katha catches and small prawns make up a large part of this. The highest catch $(20.02 \mathrm{~kg} / \mathrm{ha})$ of giant freshwater prawn Macrobrachium rosenbergii was recorded in 2000 and 2002 and lower catches $(9.74 \mathrm{~kg} / \mathrm{ha})$ were recorded in 2001. Family and species level detailed results are also presented in Appendix-1.

\subsubsection{Snakeheads}

Three species of snakeheads (Channa spp.) made up this group. Snakeheads ranked third among the group catches. Highest production (135 kg/ha) of snakehead was recorded in 2002. Channa marulius showed the highest catch $(117.02 \mathrm{~kg} / \mathrm{ha})$ within the Snakehead group in 2002. The catch of Channa striata decreased after showing a maximum catches of $35.24 \mathrm{~kg} / \mathrm{ha}$ in 1999. The catch of Channa punctata was always the lowest within this group. The catch of Channa punctata remained very unpredictable 
varying from $9.91 \mathrm{~kg} / \mathrm{ha}$ in 1998 to only 0.89 $\mathrm{kg} / \mathrm{ha} 2002$. It is worth noting that Channa punctata is one of the species severely affected by ulcerative disease (EUS) which must have impacted catches [17]. Catches of Channa punctata may also have been affected by recruitment over-fishing in floodplains where they breed. Family and species level detailed results are presented in Appendix-1.

\subsubsection{Small barbs}

Small barbs were represented by five species of barbs of the genus Puntius and Pethia. The catch remained about $2-10 \%$ of total Katha catch during study years. Puntius sophore constituted the highest catch about $29.90 \mathrm{~kg} / \mathrm{ha}$ in 1998, and gradually decreased until 2000 but increased to $26.76 \mathrm{~kg} / \mathrm{ha}$ in 2002. Analysis of catches from Kathas in this river showed that Pethia sp made up the smallest species group. Family and species level detailed results are presented in Appendix-1.

\subsubsection{Large and medium miscellaneous species}

The fishes of this group are large and medium sized fishes such as feather backs (Chitata chitala, Notopterus notopterus), Mastacembelus armatus, Nandus nandus. Like barbs, the contribution of this group was one of the lowest and varied between 4 to $15 \%$ of the total Katha catch. The lowest catch (12.80 kg/ha) was recorded in 1997 and the highest catch (78.96 $\mathrm{kg} / \mathrm{ha}$ ) was recorded in 2001 . The catch of other years fluctuated. The catch of contributing species in this group showed irregular pulses over years. Family and species level detailed results are presented in Appendix-1.

\subsubsection{Small miscellaneous species}

A number of small sized fish from different groups of fish constitute this group. The contribution of this group ranged from $1.7 \%$ (1997) to $7.7 \%(1998)$ of the total catch. The catch of other years remained similar. The highest catch of around $44 \mathrm{~kg} / \mathrm{ha}$ was recorded in 2000. Parambassis ranga showed the highest catch of about $34.78 \mathrm{~kg} / \mathrm{ha}$ in 2000 . Family and species level detailed results are also presented in Appendix-1.

\subsection{Overall Catch Trends of Fishes}

The variation of main species in different years and their catch pattern in the Khata reveals that eight species (Mystus vittatus, Wallago attu, Channa marulius, Labeo rohita, Macrobrachium lamarrei, Mystus sp, Nandus nandus and Labeo gonius) showed increasing catch trends and nine species (Mystus seenghala, Noptoterus notopterus, Channa striatus, Puntius sophore, Systomus sarana, Neotropius atherinoides, Sperata aor, Macrobrachium rosenbergii and Macrobrachium malcolmsonit) showed decreasing trends. This reveals that among the 18 main species the 'increasing trends' species contributed $61.0 \%$ and the 'decreasing trends' species contributed $28.0 \%$ of the overall catch. Present study shows that Katha catches were dominated by six main species (Neotropius atherinoides, Mystus vittatus, Labeo rohita, Wallago attu, Channa striatus and Channa marulius) and the combined overall catch was $589 \pm 180 \mathrm{~kg} / \mathrm{ha} /$ year. Neotropius atherinoides, which was the most abundant species in 1997, showed a huge decrease in catch the following years, so that it was no longer within the list of abundant species. Channa marulius appeared as the most abundant species through succession and replacing other overexploited species.

It is worth noting that Katha fisheries in the river Titas showed a minor change in species composition (most abundant species). Good examples were the species Mystus vittatus, Wallago attu, Channa marulius and Labeo rohita, and their combined contribution was about half of the annual Katha catch. In a study during 2001 and 2002 from an adjacent section of the same river it was found that Wallago attu, Notopterus notopterus, Macrobrachium rosenbergii and Macrobrachium malcolmsonii contributed $12.48 \%, 2.57 \%, 2.88 \%$ and $1.18 \%$ during Katha fishing season [18] which compares well with the present findings. In the Katha fishery, the perennial component of the catches were Mystus vittatus, Wallago attu, Channa marulius and Labeo rohita which accounted for $13.72 \%$, $11.46 \%, 10.05 \%$ and $8.02 \%$ of the overall catch.

\subsection{Costs and Benefits}

Cost - benefit analysis over the study period (1997-2002) found that annual costs and benefits varied proportionately overtime. Katha census records showed increased costs for Katha construction in 1999 compared to 1997 and costs remained steady until 2002 due to economic scale. However, benefits increased suddenly in the 1999 season compared to previous seasons and remained steady from 2000 to 2002. The lowest net benefit (BDT 9,885 or USD 225) per 


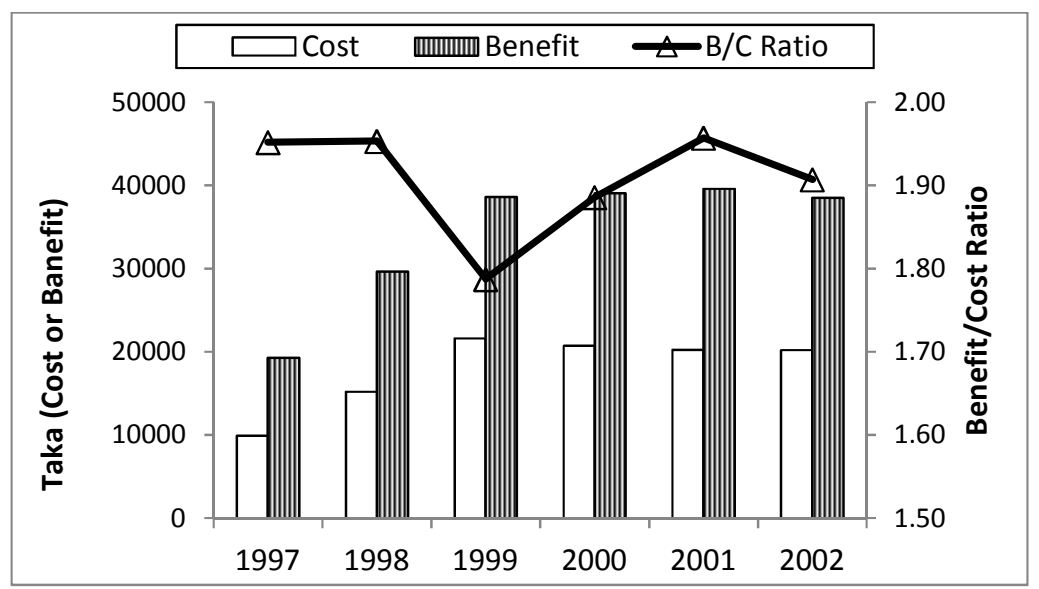

Fig. 7. Cost-benefits of Katha catch in the river Titas

Katha was found in 1997 and the highest net benefit (BDT 21,629 or USD 446) per Katha was found in 1999. The benefit/cost ratio for Kathas during 1997- 2002 were found to be 1.95, 1.95, $1.79,1.89,1.96$ and 1.91 respectively. Costbenefit analysis of Kathas has been studied by [18] from an adjacent section of the same river and found net benefit of BDT 10430 per Katha per year during 2001-2002. Titas G-G is in the mainstream of the river Titas and is comparatively deeper compared to [18] study area, and may represent a better area for fish to stay safely. The trends for costs and benefits of the Titas G-G Katha fishery from 1997 to 2002 are shown in Fig. 7.

\section{CONCLUSIONS}

Control measures are necessary to limit the deployment of Katha fishing considering the appropriateness of its extent, the number of Kathas in a waterbody, and the species mix of fish at a site. Katha fishing may be considered as harmful as brood-fish of many of the riverine resident species are easily caught. The study has provided evidence that the Katha fishery restricts recruitment to the inland openwater fishery and therefore results in an overall lowering of production. Also the relative abundance of top predators in Kathas could be an indication of biological over fishing. On the other hand it is a very efficient device to harvest big carnivores (top predators) like Wallago attu, Channa marulius, Channa striatus etc. So from the point of view of fisheries management, Kathas represent a dilemma. Although this study may not be solely conclusive, it appears that the Katha fishery in the river system generally has a detrimental impact on fisheries resources as well as reducing fishing opportunities for poor and marginal fishers. Further research is needed on this to reach to a decision on this fish aggregating device, whether it should be continued or fully stopped in the inland open water fisheries management system, where community based fisheries management has to real alternative to promote.

\section{COMPETING INTERESTS}

Author has declared that no competing interests exist.

\section{REFERENCES}

1. DoF (Department of Fisheries). National Fish Week 2014 Compendium (In Bangla). Department of Fisheries, Ministry of Fisheries and Livestock, Bangladesh; 2014.

2. DoF (Department of Fisheries). National Fish Week 2015 Compendium (In Bangla). Department of Fisheries, Ministry of Fisheries and Livestock, Bangladesh; 2015.

3. Paul MT, Sultana, P, Islam, N. Lessons from community based management of floodplain fisheries in Bangladesh. Journal of Environmental Management. 2003;69: 307-321.

4. Khabir A, Munir A. Fish Sanctuary Book, TARA; 2002.

5. Haque M. Study of fish catch composition in relation to different types of Katha materials in the three river systems of Netrokona district. CBFM-2, WorldFish Center funded research project; 2004. 
6. Kadir MM, Hossain MM, Kabir MS. Patterns of fish catches in rivers and open beels. Paper presented in the national workshop on CBFM and future strategies for inland fisheries in Bangladesh; 1999.

7. Azher SA, Dewan S, Wahab MA, Habib MAB and Mustafa MG. Impacts of fish sanctuaries on production and biodiversity of fish and prawn in Dopi beel, Joanshahi haor, Kishoregonj. Bangladesh J. Fish, Special Issue. 2007;30:23-36.

8. Mustafa MG, Brooks, AC. Status of Fisheries Resource and Management Approach in the Open Beels of Bangladesh: A Comparative Case Study. Asian Fisheries Science. 2008;21:189-203.

9. Clarke KR. Non-parametric multivariate analysis of changes in community structure. Aust. J. Ecol. 1993;18:117-143.

10. Seaby $\mathrm{RMH}$, Henderson PA. Community Analysis Packages; 3.0 Pisces Conservation Ltd. Lymington, UK; 2004.

11. Beals EW. Bray-Curtis ordination: An effective strategy for analysis of multivariate ecological data. Advances Ecological Research. 1984;14:1-55.

12. Henderson PA, Seaby, RMH. Species diversity and richness. 3.03 Pisces Conservation Ltd. Lymington, UK; 2004.
13. Haque $M$, Ahmed M, Mustafa MG. Preferences of fishes 0 different types of Katha materials used in sanctuaries in three rivers of Netrokona. Bangladesh J. Fish. Special Issue. 2007;30:153-164.

14. Binay KC, Azad SA, Siddiqa A. Moinul KM. Conservation status of fin fish and shell fish in Haria beel in Bangladesh and prospect for utilizing the beel for conservation and production of fish. Journal of Crop and Weed. 2013;9(1):3851.

15. Chakraborth BK, Mirza MJA. Status of aquatic resources in Someswari River in Northern Bangladesh. Asian Fisheries Science. 2010;23:174-193.

16. Chakraborty BK, Azad SA, Siddiqa A, Hasin KMM. Status of aquatic biodiversity in Meduary beel in Bangladesh. Bangladesh J. Environ. Sci. 2012;23:7076.

17. Mandal S, Mandal M, Pak NK, Halder PK, Basu PS. R-factor in Proteus vulgaris from ulcerative disease of fish, Channa punctatus. Indian J. Exp. Biol. 2002;40 (5):614-616.

18. Sagir AM, Aktheruzzaman M, Thompson $P$. Khata Fishery in the river Titas, Brahmanbaria, Bangladesh; 2002. 


\section{APPENDIX}

Appendix-1. The taxonomic group used in the Katha catch analysis of the river Titas and the taxa contributed to each group by weight ( $\mathrm{kg} / \mathrm{ha}$ ) to the Katha catches

\begin{tabular}{|c|c|c|c|c|c|c|c|c|c|}
\hline \multirow[t]{2}{*}{ Group } & \multirow[t]{2}{*}{ Family } & \multirow[t]{2}{*}{ Scientific name } & \multirow[t]{2}{*}{ Common name } & \multirow{2}{*}{\begin{tabular}{|l|}
$\begin{array}{l}\text { Catch } \\
\text { (kg/ha) }\end{array}$ \\
1997 \\
\end{tabular}} & \multirow{2}{*}{\begin{tabular}{|l|}
$\begin{array}{l}\text { Catch } \\
\text { (kg/ha) }\end{array}$ \\
1998 \\
\end{tabular}} & \multirow{2}{*}{\begin{tabular}{|l|}
$\begin{array}{l}\text { Catch } \\
\text { (kg/ha) }\end{array}$ \\
1999 \\
\end{tabular}} & \multirow{2}{*}{\begin{tabular}{|l|}
$\begin{array}{l}\text { Catch } \\
\text { (kg/ha) }\end{array}$ \\
2000 \\
\end{tabular}} & \multirow{2}{*}{\begin{tabular}{|l|}
$\begin{array}{l}\text { Catch } \\
\text { (kg/ha) }\end{array}$ \\
2001 \\
\end{tabular}} & \multirow{2}{*}{$\begin{array}{l}\begin{array}{l}\text { Catch } \\
\text { (kg/ha) }\end{array} \\
2002 \\
\end{array}$} \\
\hline & & & & & & & & & \\
\hline Large and & Bagridae & Sperata aor & Long-whiskered catfish & 6.32 & 13.53 & 19.30 & 27.89 & 17.81 & 7.40 \\
\hline medium sized & Bagridae & Mystus bleekeri & Day's mystus & 0.00 & 4.90 & 22.50 & 8.48 & 2.83 & 10.66 \\
\hline \multirow[t]{6}{*}{ Catfishes } & Siluridae & Ompok pabda & Pabda catfish & 3.80 & 2.58 & 1.21 & 5.14 & 11.62 & 8.71 \\
\hline & Siluridae & Ompok bimaculatus & Butter catfish & 4.73 & 0.00 & 0.61 & 1.79 & 0.00 & 0.00 \\
\hline & Siluridae & Wallago attu & Wallago Catfish & 21.83 & 36.99 & 61.10 & 94.54 & 100.09 & 100.23 \\
\hline & Heteropneustidae & Heteropneustes fossilis & Stinging catfish & 0.16 & 0.00 & 0.00 & 0.00 & 0.00 & 0.00 \\
\hline & Clariidae & Clarias batrachus & Philippine catfish & 0.00 & 0.00 & 0.07 & 0.29 & 0.00 & 0.00 \\
\hline & Bagridae & Rita rita & Rita & 0.00 & 0.00 & 0.00 & 0.00 & 0.03 & 0.00 \\
\hline Small & Bagridae & Mystus vittatus & Striped dwarf catfish & 7.54 & 59.53 & 84.31 & 92.94 & 130.82 & 97.39 \\
\hline \multirow[t]{4}{*}{ catfishes } & Bagridae & Mystus sp. & Catfish & 48.48 & 0.00 & 0.00 & 8.16 & 12.30 & 5.34 \\
\hline & Schilbeidae & Neotropius atherinoides & Indian potasi & 54.38 & 20.26 & 9.47 & 9.09 & 15.33 & 15.63 \\
\hline & Bagridae & Sperata seenghala & Giant river-catfish & 5.92 & 31.83 & 17.25 & 17.8 & 22.32 & 32.01 \\
\hline & Sisoridae & Gagata gagata & Gangetic gagata & 0.69 & 0.00 & 0.00 & 0.00 & 0.00 & 0.00 \\
\hline Major and & Cyprinidae & Labeo rohita & Roho labeo & 29.35 & 16.11 & 53.00 & 64.05 & 65.63 & 63.69 \\
\hline \multirow[t]{6}{*}{ Minor carps } & Cyprinidae & Gibelion catla & Catla & 4.04 & 0.00 & 0.00 & 0.00 & 0.00 & 0.00 \\
\hline & Cyprinidae & Cyprinus carpio & Common carp & 0.75 & 0.00 & 0.00 & 0.00 & 8.68 & 4.06 \\
\hline & Cyprinidae & Cirrhinus mrigala & Carps & 0.29 & 0.00 & 0.00 & 0.00 & 0.00 & 0.00 \\
\hline & Cyprinidae & Labeo gonius & Kuria labeo & 0.53 & 0.22 & 5.11 & 28.37 & 34.62 & 29.22 \\
\hline & Cyprinidae & Labeo calbasu & Orangefin labeo & 4.30 & 6.18 & 11.70 & 15.72 & 20.76 & 5.70 \\
\hline & Cyprinidae & Systomus sarana & Olive barb & 0.21 & 26.98 & 18.04 & 16.69 & 23.51 & 17.43 \\
\hline \multirow[t]{5}{*}{ Prawns } & Palaemonidae & Macrobrachium malcolmsonii & Monsoon river prawn & 14.18 & 3.02 & 16.81 & 1.03 & 18.62 & 29.62 \\
\hline & Palaemonidae & Macrobrachium villosimanus & Dimua river prawn & 9.37 & 1.22 & 4.49 & 20.30 & 7.48 & 3.48 \\
\hline & Palaemonidae & Macrobrachium rogenbergii & Giant river prawn & 19.39 & 15.81 & 16.48 & 20.21 & 9.74 & 20.02 \\
\hline & Palaemonidae & Macrobrachium lamarrei & Kuncho river prawn & 19.25 & 16.87 & 34.07 & 31.34 & 43.19 & 42.30 \\
\hline & Palaemonidae & Macrobrachium birmanicum & Birma river prawn & 0.00 & 0.54 & 4.67 & 2.53 & 0.00 & 4.86 \\
\hline \multirow[t]{3}{*}{ Snake heads } & Channidae & Channa marulius & Great snakehead & 2.60 & 33.42 & 53.82 & 75.54 & 89.31 & 117.02 \\
\hline & Channidae & Channa striata & Striped snakehead & 7.64 & 35.24 & 21.89 & 15.38 & 13.77 & 17.51 \\
\hline & Channidae & Channa punctata & Spotted snakehead & 0.00 & 9.91 & 7.53 & 2.79 & 0.06 & 0.89 \\
\hline \multirow[t]{3}{*}{ Small barbs } & Cyprinidae & Puntius sophore & Pool barb & 19.86 & 29.90 & 13.75 & 14.22 & 16.49 & 26.76 \\
\hline & Cyprinidae & Pethia gelius & Golden barb & 2.34 & 0.00 & 0.00 & 0.00 & 0.00 & 0.00 \\
\hline & Cyprinidae & Pethia conchonius & Rosy barb & 0.36 & 0.00 & 0.00 & 0.00 & 0.00 & 0.00 \\
\hline
\end{tabular}


Mustafa; AIR, 10(2): 1-14, 2017; Article no.AIR.33850

\begin{tabular}{|c|c|c|c|c|c|c|c|c|c|}
\hline Group & Family & Scientific name & Common name & $\begin{array}{l}\text { Catch } \\
\text { (kg/ha) }\end{array}$ & $\begin{array}{l}\text { Catch } \\
\text { (kg/ha) }\end{array}$ & $\begin{array}{l}\text { Catch } \\
\text { (kg/ha) }\end{array}$ & $\begin{array}{l}\text { Catch } \\
\text { (kg/ha) }\end{array}$ & $\begin{array}{l}\text { Catch } \\
\text { (kg/ha) }\end{array}$ & $\begin{array}{l}\text { Catch } \\
\text { (kg/ha) }\end{array}$ \\
\hline & & & & 1997 & 1998 & 1999 & 2000 & 2001 & 2002 \\
\hline \multirow{5}{*}{$\begin{array}{l}\text { Large medium } \\
\text { species }\end{array}$} & Cyprinidae & Pethia phutunio & Spottedsail barb & 0.75 & 0.00 & 0.00 & 0.00 & 0.00 & 0.87 \\
\hline & Cyprinidae & Pethia ticto & Ticto barb & 0.00 & 1.74 & 0.00 & 0.00 & 0.00 & 0.00 \\
\hline & Notopteridae & Notopterus notopterus & Bronze featherback & 1.33 & 31.28 & 14.98 & 23.99 & 23.16 & 20.40 \\
\hline & Notopteridae & Chitala chitala & Clown knifefish & 0.00 & 0.00 & 0.00 & 1.52 & 0.00 & 0.15 \\
\hline & $\begin{array}{l}\text { Miscellaneous } \\
\text { Mastacembelidae }\end{array}$ & Mastacembelus armatus & Zig-zag eel & 1.83 & 19.46 & 28.14 & 16.55 & 26.79 & 19.82 \\
\hline \multirow{17}{*}{$\begin{array}{l}\text { Small misc } \\
\text { species }\end{array}$} & Nandidae & Nandus nandus & Gangetic leaffish & 9.64 & 19.91 & 11.05 & 15.10 & 29.01 & 35.27 \\
\hline & Ambassidae & Parambassis ranga & Indian glassy fish & 1.13 & 17.76 & 13.54 & 34.78 & 16.92 & 17.73 \\
\hline & Ambassidae & Parambassis sp. & Glassy fish & 2.65 & 12.24 & 0.00 & 3.39 & 0.00 & 0.89 \\
\hline & Osphronemidae & Trichogaster fasciata & Banded gourami & 0.00 & 4.21 & 5.86 & 2.63 & 1.91 & 0.58 \\
\hline & Mastacembelidae & Macrognathus Pancalus & Barred spiny eel & 0.00 & 0.00 & 5.65 & 0.67 & 0.00 & 0.27 \\
\hline & Osphronemidae & Trichogaster lalius & Dwarf gourami & 0.00 & 2.34 & 0.00 & 0.00 & 0.00 & 0.00 \\
\hline & Cyprinidae & Chela cachius & Minnows & 0.00 & 0.00 & 1.09 & 0.00 & 0.00 & 0.00 \\
\hline & Osphronemidae & Trichogaster chuna & Honey gourami & 0.00 & 0.00 & 0.13 & 0.84 & 0.21 & 0.00 \\
\hline & Cyprinidae & Salmophasia sp. & Finescale razorbelly minnow & 0.00 & 0.00 & 0.00 & 0.00 & 0.00 & 1.18 \\
\hline & Nemacheilidae & Nemacheilus sp. & Loach & 0.41 & 0.00 & 0.00 & 0.29 & 0.00 & 0.00 \\
\hline & Cyprinidae & Osteobrama cotio & Minnows & 0.00 & 0.00 & 0.40 & 0.00 & 0.00 & 0.00 \\
\hline & Tetradontidae & Tetradon sp. & Milkspotted puffer & 0.69 & 0.00 & 0.00 & 0.00 & 0.00 & 0.00 \\
\hline & Cyprinidae & Amblypharyngodon Mola & Mola carplet & 0.23 & 0.00 & 0.00 & 0.00 & 0.00 & 0.00 \\
\hline & Clupeidae & Gudusia chapra & Indian river shad & 0.00 & 0.00 & 0.00 & 0.09 & 0.00 & 0.00 \\
\hline & Badidae & Badis badis & Badis & 0.00 & 0.00 & 0.02 & 0.03 & 0.00 & 0.00 \\
\hline & & Unknown fish sp-1 & & 0.00 & 0.00 & 0.00 & 0.30 & 0.00 & 1.62 \\
\hline & & Unknown fish sp-2 & & 0.00 & 0.00 & 0.00 & 0.54 & 0.00 & 3.28 \\
\hline
\end{tabular}

(0) 2017 Mustafa; This is an Open Access article distributed under the terms of the Creative Commons Attribution License (http://creativecommons.org/licenses/by/4.0), which permits unrestricted use, distribution, and reproduction in any medium, provided the original work is properly cited.

Peer-review history:

The peer review history for this paper can be accessed here:

http://sciencedomain.org/review-history/19628 